\title{
EFEKTIVITAS LAYANAN INFORMASI DENGAN PENDEKATAN PROBLEM BASED LEARNING UNTUK MENINGKATKAN KEBIASAAN BELAJAR SISWA
}

\author{
Lisa Mardian Nova ${ }^{1)}$, Firman Firman ${ }^{2)}$, Indah Sukmawati ${ }^{3)}$
}

Email : firman@konselor.org

\begin{abstract}
Abstrak: Dewasa ini ditemukan sebagian siswa memiliki kebiasaan belajar yang kurang mendukung, yang ditunjukkan dengan perilaku siswa hanya belajar pada saat ada tugas dan ketika akan menghadapi ujian saja. Ada siswa yang sudah tidak mau mencatat hal-hal penting yang dijelaskan guru, selain itu juga ada siswa yang menunda tugas. Penelitian ini bertujuan mengungkapkan: (1) Peningkatan kebiasaan belajar siswa kelompok eksperimen sebelum (pretest) dan setelah (posttest) diberikan perlakuan layanan informasi dengan pendekatan problem based learning; (2) Peningkatan kebiasaan belajar siswa kelompok kontrol pada sebelum (pretest) dan setelah (posttest) tanpa diberi perlakuan layanan informasi dengan pendekatan problem based learning; (3) Perbedaan peningkatan kebiasaan belajar siswa antara kelompok eksperimen yang diberikan perlakuan layanan informasi dengan pendekatan problem based learning dengan siswa kelompok kontrol yang tidak diberikan perlakuan layanan informasi dengan pendekatan problem based learning.
\end{abstract}

Penelitian ini merupakan penelitian deskriptif kuantitatif dengan pendekatan Quasy-Experiment. Subjek penelitiannya siswa kelas VIII.E SMPN 2 Sawahlunto yang berjumlah 20 orang sebagai kelompok eksperimen dan kelas VIII.G SMPN 2 Sawahlunto yang berjumlah 20 orang sebagai kelompok kontrol. Instrumen yang digunakan adalah kuesioner (angket). Data kemudian dianalisis dengan menggunakan rumus Wilcoxon Signed Ranks test dan Kolmogorov-Smirnov Two Independent Sampel dengan bantuan program Statistical Product and Service Solution (SPSS) versi 20.

Berdasarkan temuan penelitian ini yaitu: (1) terdapat peningkatan yang signifikan pada kebiasaan belajar siswa dari efektivitas layanan informasi pada kelompok eksperimen melalui pendekatan problem based learning, (2) tidak terdapat peningkatan yang signifikan pada kebiasaan belajar siswa dari efektivitas layanan informasi pada kelompok kontrol melalui pendekatan problem based learning, (3) terdapat perbedaan yang signifikan peningkatan kebiasaan belajar siswa pada kelompok eksperimen dengan kelompok kontrol. Berdasarkan temuan di atas, dapat disimpulkan bahwa kebiasaan belajar siswa dapat ditingkatkan melalui layanan informasi dengan pendekatan problem based learning, Oleh karena itu guru BK disarankan dapat mengembangkan layanan bimbingan dan konseling terutama layanan informasi untuk membantu meningkatkan kebiasaan belajar siswa.

Keywords: Layanan Informasi, Problem Based Learning, dan Kebiasaan Belajar

\section{PENDAHULUAN}

Pelayanan bimbingan dan konseling (BK) di sekolah mengoptimalkan terwujudnya tujuan pendidikan itu sendiri. Bimbingan dan konseling (BK) mengupayakan siswa dapat mandiri dalam mengambil keputusan serta menyelesaikan masalah yang dihadapi, pelaksanaan bimbingan dan konseling di sekolah diselenggarakan oleh guru $\mathrm{BK} /$ konselor.

Bimbingan dan konseling itu sendiri adalah upaya berupa layanan yang diberikan oleh guru BK untuk membantu individu dalam menyelesaikan masalah sehingga dapat terciptanya kehidupan yang efektif sehari-hari. Bimbingan adalah bantuan atau pertolongan yang diberikan oleh seseorang kepada individu yang membutuhkan, sedangkan konseling adalah bantuan yang diberikan oleh orang yang ahli kepada individu dalam memecahkan permasalahan yang sedang dihadapi.

Pernyataan tersebut diperkuat oleh pendapat Prayitno dan Erman Amti (2009:130) yaitu:

Bimbingan adalah proses pemberian bantuan yang dilakukan oleh seorang ahli kepada individu dengan menggunakan berbagai prosedur, cara dan bahan agar individu tersebut mampu mandiri dalam memecahkan masalah-masalah yang dihadapinya.

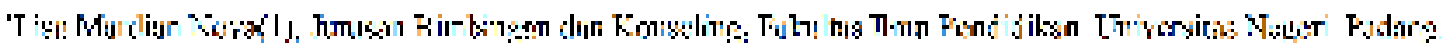

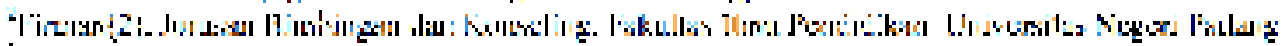

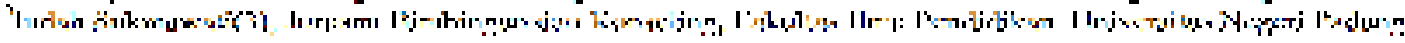

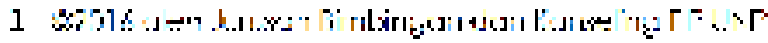

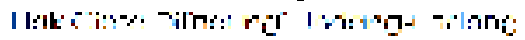


Sedangkan konseling merupakan proses pemberian bantuan yang didasarkan pada prosedur wawancara konseling oleh seorang ahli (disebut konselor) kepada individu (disebut klien) yang bermuara pada teratasinya masalah yang dihadapi klien.

Layanan informasi ialah layanan yang dimaksudkan untuk memberikan pengetahuan baru kepada peserta didik sesuai dengan kebutuhan. Menurut Dewa Ketut Sukardi (2008:61) layanan informasi adalah layanan bimbingan yang memungkinkan pihak-pihak tertentu seperti konselor dapat memberikan pengaruh yang besar kepada peserta didik dalam menerima informasi yang berguna dalam menjalani kehidupan sebagai pelajar, anggota keluarga dan masyarakat.

Tujuan dari layanan informasi ini adalah dikuasainya informasi tertentu oleh peserta layanan yaitu siswa, hal ini dipertegas oleh pendapat Prayitno (2012:50), "layanan informasi berusaha memenuhi kekurangan individu akan informasi yang mereka perlukan. Dalam layanan ini, kepada peserta layanan disampaikan berbagai informasi”.

Informasi yang diberikan beragam misalnya informasi pendidikan, informasi jabatan dan informasi sosial-budaya. Maka akan terciptalah dinamika perkembangan individu yang berpotensi positif. Layanan informasi yang diberikan hendaklah harus jelas materinya. Menurut Dewa Ketut Sukardi (2008:61) materi layanan informasi menyangkut:

1. tugas-tugas perkembangan masa remaja akhir, yaitu tentang kemampuan dan perkembangan pribadi.

2. usaha yang dapat dilakukan dalam mengenal bakat, minat, serta bentuk-bentuk penyaluran dan pengembangannya.

3. tata tertib sekolah, cara bertingkah laku, tata karma, dan sopan santun.

4. nilai-nilai sosial, adat-istiadat, dan upaya yang berlaku dan berkembang di masyarakat.

5. mata pelajaran dan pembidangannya, seperti program inti, program khusus, dan program tambahan.
6. sistem penjurusan, kenaikan kelas, dan syarat-syarat mengikuti ujian akhir.

7. fasilitas penunjang/sumber belajar.

8. cara mempersiapkan diri dalam belajar di sekolah.

9. syarat-syarat memasuki suatu jabatan, kondisi jabatan/karir serta prospeknya.

10. langkah-langkah yang perlu ditempuh guna menentukan jabatan/karir.

11. memasuki perguruan tinggi yang sejalan dengan cita-cita karir.

12. pelaksanaan pelayanan bantuan untuk masalah pribadi, sosial, belajar, dan karir.

Dari beragam materi yang diberikan, seorang guru BK harus memiliki jiwa kreativitas yang tinggi, sehingga konselor dalam memberikan layanan informasi dengan menyenangkan.Salah satu kelemahan layanan informasi ini ialah sasaran layanan atau siswa dengan mudah merasa bosan apabila yang diterapkan hanya metode ceramah saja.Oleh karena itu guru BK harus menggunakan pendekatanpendekatan pembelajaran yang inovatif agar tujuan dari pemberian layanan informasi dapat terwujud. Hal ini sejalan dengan pendapat Wina Sanjaya (2012:127) menjelaskan, "pendekatan digunakan untuk memperoleh kesuksesan atau keberhasilan dalam menciptakan strategi pembelajaran sehingga tujuan pembelajaran dapat tercapai". Salah satu pendekatan yang dapat digunakan ialah pendekatan problem based learning (pembelajaran berbasis masalah).

Pendekatan problem based learning atau pembelajaran berbasis masalah adalah suatu pendekatan pembelajaran yang menggunakan masalah dunia nyata sebagai suatu konteks bagi siswa untuk belajar tentang cara berfikir kritis dan keterampilan memecahkan masalah. Menurut Kunandar (2010:354) pendekatan problem based learning adalah suatu pendekatan pembelajaran yang menggunakan masalah dunia nyata sebagai suatu konteks bagi siswa untuk belajar tentang cara berfikir kritis dan keterampilan pemecahan masalah, serta untuk memperoleh pengetahuan dan konsep yang esensial dari materi pelajaran.

Pelaksanaan layanan informasi, peneliti tertarik pada pendekatan problem 
based learning ini karena banyak sekali keunggulan yang dapat diperoleh oleh siswa nantinya, seperti: (1) peserta didik yang belajar memecahkan suatu masalah maka mereka akan menerapkan pengetahuan yang dimilikinya atau berusaha mengetahui pengetahuan yang diperlukan, (2) peserta didik dapat meningkatkan kemampuan berpikir kritis dan menumbuhkan inisiatif, (3) peserta didik dilatih untuk mengembangkan caracara menemukan, bertanya, mengungkapkan, dan menjelaskan. Maka dari pendekatan yang dilakukan tersebut, akan terjadi pembelajaran yang bermakna.

Setiap hari, bahkan setiap saat manusia selalu dihadapkan dengan masalah yang menuntut penyelesaiannya, begitu pula halnya peserta didik. Hakikatnya seorang siswa memiliki kebiasaan belajar yang baik seperti kebiasaan pembuatan jadwal pelajaran, membaca, mengulangi bahan pelajaran, konsentrasi dalam belajar dan mengerjakan tugas. Kebiasaan belajar itu sendiri menurut Aunurrahman (2012:123) adalah salah satu bentuk upaya untuk mengkondisikan atau membiasakan suatu perilaku, yaitu perilaku belajar.

Pendapat tersebut diperkuat oleh Djaali (2012:12), "kebiasaan belajar sebagai cara atau teknik yang menetap pada diri siswa pada waktu menerima pelajaran, membaca buku, mengerjakan tugas dan pengaturan waktu untuk menyelesaikan kegiatan”. Dari pendapat para ahli dapat disimpulkan bahwa kebiasaan belajar adalah perilaku yang tertanam pada diri seseorang yang dibuktikan dari aktivitas belajar.

Sikap dan kebiasaan belajar berpengaruh terhadap hasil yang dicapai, karena dengan membiasakan diri belajar dengan baik akan diperoleh hasil belajar yang memuaskan.

Kenyataannya pada saat sekarang ini banyak ditemukan kebiasaan belajar siswa yang masih rendah, siswa hanya belajar pada saat ada tugas dan ketikaakan menghadapi ujian saja. Ada siswa sudah tidak mau mencatat hal-hal penting yang dijelaskan guru, selain itu juga ada siswa yang menunda tugas. Pernyataan ini diperkuat oleh hasil penelitian yang dilakukan oleh Frisa Indriyani (2011:41) menyatakan sebesar $43,42 \%$ siswa termasuk ke dalam kategori kurang baik dalam pemanfaatan waktu belajar di luar jadwal belajar sekolah.

Siswa memiliki kebiasaan belajar yang berbeda-beda, ada siswa yang menunjukkan tingkat kebiasaan belajar yang tinggi dan ada pula yang menunjukkan kebiasaan belajar yang rendah, hal ini disebabkan karena siswa memiliki potensi yang berbeda-beda pula. Siswa dikatakan telah memiliki kebiasaan belajar yang baik apabila siswa telah mampu melakukan tugas belajar tanpa ketergantungan terhadap orang lain. Pendapat ini sejalan dengan penelitian yang dilakukan oleh Sherly Yosevia (2013:44) mengungkapkan kesadaran siswa dalam menyelesaikan tugas terstruktur berada dalam kategori cukup dengan persentase sebanyak 44,35\% siswa.

Kebiasaan belajar siswa yang tinggi juga didukung dengan adanya sarana dan prasarana belajar yang memadai. Dari adanya sarana dan prasarana belajar yang lengkap siswa akan lebih termotivasi dalam belajar seperti melengkapi catatan. Berdasarkan hasil penelitian yang dilakukan oleh Wulandari Cristal (2013:51) terungkap keterampilan mencatat siswa masih berada dalam kategori kurang baik dimana $41,9 \%$ siswa belum mencatat dengan cepat, dan $51,4 \%$ siswa belum memeriksa ketepatan dan kelengkapan isi catatan.

Layanan informasi yang dilaksanakan oleh guru pembimbing selama ini belum efektif dalam meningkatkan kebiasaan belajar siswa, karena itulah dalam layanan informasi perlu digunakan pendekatan pembelajaran problem based learning agar permasalahan yang dialami siswa dalam kebiasaan belajar dapat diatasi.

Peneliti tertarik melakukan penelitian di SMP N 2 Sawahlunto karena sekolah ini termasuk sekolah yang favorit di kota Sawahlunto, serta peneliti juga menemukan adanya fenomena tentang kebiasaan belajar yang masih rendah seperti tidak adanya pembiasaan belajar yang teratur dari siswa, dan kurangnya konsentrasi dalam kelas pada saat proses belajar mengajar berlangsung.

\section{METODE PENELITIAN}

Penelitian ini merupakan penelitian eksperimen yang menguji hipotesis yang menguji hubungan sebab akibat diantara variabel 
yang diteliti. Subjek penelitian meliputi siswa kelas VIII SMPN 2 Sawahlunto yang terdiri dari 20 orang siswa yang akan dijadikan sebagai subyek penelitian pada kelompok eksperimen dan 20 orang siswa pada kelompok kontrol. Instrumen yang digunakan adalah angket dengan lima alternatif jawaban yaitu Selalu, Sering, Kadang-kadang, Jarang dan Tidak pernah. Teknik analisis data menggunakan presentase (Anas Sudjono, 2009: 318) dengan rumus sebagai berikut:

$$
\text { Mutu }=\frac{\text { Skor Perolehan }}{\text { Skor Ideal }} 100
$$

Selanjutnya untuk melihat deskripsi data hasil pretest dan posttest digunakan teknik statistik yaitu dengan mencari skor mean (ratarata), standar deviasi, range, skor minimum dan skor maksimum. Menurut Tulus Winarsunu (2002: 59) rumus- rumus tersebut adalah:

1. Mean, yaitu $\mathrm{M}=\frac{\sum \mathrm{fX}}{\mathrm{N}}$

2. Standar Deviasi, yaitu $\mathrm{SD}=$

$$
\sqrt{\left(\frac{\sum \mathrm{fX}^{2}}{\mathrm{~N}}\right)-\left(\frac{\sum \mathrm{fX}}{\mathrm{N}}\right)^{2}}
$$

3. Range, yaitu Range $=(\mathrm{Xt}-\mathrm{Xr})+1$

Keterangan:

$\sum \mathrm{fX}=$ Jumlah responden yang memilih (frekuensi) x nilai tengah setiap interval.

$\mathrm{N} \quad=$ Jumlah responden

$\mathrm{M}=$ Mean

SD $=$ Standar Deviasi

Range $=$ Rentangan dari skor

$\mathrm{Xt}=$ Skor Tertinggi

$\mathrm{Xr} \quad=$ Skor Terendah

Setelah data diolah menggunakan rumus statistik kemudian ditetapkan kriteria penilaian masing-masing data yang diperoleh yang mengacu kepada batasan yang dikemukakan oleh Anas Sudijono (2009: 329):

Tabel

Kriteria Pengolahan Data Deskriptif Hasil Penelitian

\begin{tabular}{|l|c|}
\hline Kriteria & Skor \\
\hline Sangat Baik & $\geq$ Mean $+1,5$ SD \\
\hline Baik & $\geq$ Mean $+0,5$ SD \\
& s/d $<$ Mean $+1,5$ SD \\
\hline Sedang & $\geq$ Mean-0,5 SD \\
s/d $<$ Mean $+0,5$ SD \\
\hline
\end{tabular}

\begin{tabular}{|l|c|}
\hline Rendah & $\begin{array}{c}\geq \text { Mean-1,5 SD } \\
\text { s/d }<\text { Mean-0,5 SD }\end{array}$ \\
\hline Sangat Rendah & $<$ Mean-1,5 SD \\
\hline
\end{tabular}

Untuk melihat perbedaan pemahaman siswa antara sebelum dan sesudah diberi perlakuan dengan layanan informasi dengan pendekatan problem based learning, dilakukanlah analisis data dengan menggunakan metode teknik statistik non parametrik yaitu: Wilcoxon Signed Ranks Test, menggunakan rumus yang dikemukakan oleh Wahid Sulaiman (2003: 79)

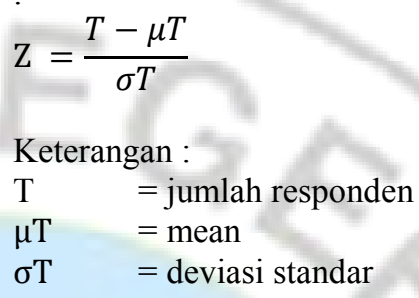

Sedangkan untuk melihat perbedaan kebiasaan belajar siswa antara kelompok eksperimen yang diberi perlakuan (layanan informasi dengan pendekatan problem based learning) dengan kelompok kontrol yang tidak di beri perlakuan. dilakukanlah analisis data dengan menggunakan metode teknik statistik non parametrik yaitu: Test KolmogorovSmirnov dua sampel, yaitu dengan menggunakan program SPSS versi 20 .

\section{HASIL}

Berdasarkan hasil pengolahan data yang sesuai tujuan penelitian yaitu untuk: 1) Menguji perbedaan peningkatan kebisaan belajar siswa pada kelompok eksperimen sebelum dan setelah diberikan perlakuan layanan informasi dengan pendekatan problem based learning. 2) Menguji perbedaan peningkatan kebiasaan belajar siswa kelompok kontrol tanpa perlakuan layanan informasi dengan pendekatan problem based learning. 3) Menguji perbedaan peningkatan kebiasaan belajar siswa kelompok eksperimen yang diberikan perlakuan layanan informasi dengan pendekatan problem based learning dengan siswa kelompok kontrol yang tidak diberikan perlakuan. Maka dapat diuraikan hasil penelitian sebagai berikut: 
Hasil Pretest dan Posttest Kebiasaan Belajar Siswa Kelompok Eksperimen

1. Perbedaan Kebiasaan Belajar Siswa

\begin{tabular}{|c|c|c|c|c|c|c|c|}
\hline \multirow{3}{*}{$\begin{array}{l}\mathbf{N} \\
\mathbf{O}\end{array}$} & \multirow{3}{*}{$\begin{array}{c}\text { Respon } \\
\text { den }\end{array}$} & \multicolumn{6}{|c|}{ Kelompok Eksperimen } \\
\hline & & \multicolumn{3}{|c|}{ Pretest } & \multicolumn{3}{|c|}{ Postest } \\
\hline & & Skor & $\%$ & $\begin{array}{l}\text { Kate } \\
\text { gori }\end{array}$ & Skor & $\%$ & $\begin{array}{l}\text { Kate } \\
\text { gori }\end{array}$ \\
\hline 1 & $\mathrm{AB}$ & 151 & 75.5 & $S$ & 156 & 78 & B \\
\hline 2 & AY & 155 & 77.5 & B & 169 & 84.5 & SB \\
\hline 3 & $\mathrm{BO}$ & 126 & 63 & SR & 155 & 77.5 & $B$ \\
\hline 4 & CF & 139 & 69.5 & $R$ & 144 & 72 & $S$ \\
\hline 5 & $\overline{D R}$ & 142 & 71 & $S$ & 161 & 80.5 & $B$ \\
\hline 6 & DHR & 151 & 75.5 & $S$ & 159 & 79.5 & B \\
\hline 7 & $\mathrm{DO}$ & 146 & 73 & S & 164 & 82 & $B$ \\
\hline 8 & FMN & 165 & 82.5 & B & 182 & 91 & SB \\
\hline 9 & GR & 138 & 69 & $\mathrm{R}$ & 161 & 80.5 & B \\
\hline 10 & IY & 144 & 72 & $\mathrm{~S}$ & 159 & 79.5 & $B$ \\
\hline 11 & MP & 159 & 79.5 & $B$ & 167 & 83.5 & SB \\
\hline 12 & MS & 151 & 75.5 & $S$ & 158 & 79 & $B$ \\
\hline 13 & $\mathrm{NA}$ & 157 & 78.5 & $B$ & 173 & 86.5 & SB \\
\hline 14 & PP & 142 & 71 & $S$ & 176 & 88 & SB \\
\hline 15 & $\mathrm{RLH}$ & 153 & 76.5 & $S$ & 155 & 77.5 & $B$ \\
\hline 16 & SS & 140 & 70 & $R$ & 165 & 82.5 & B \\
\hline 17 & $S$ & 134 & 67 & $\mathrm{R}$ & 142 & 71 & $S$ \\
\hline 18 & TF & 129 & 64.5 & $\mathrm{R}$ & 147 & 73.5 & $S$ \\
\hline 19 & WD & 137 & 68.5 & $\mathrm{R}$ & 159 & $\begin{array}{l}79.5 \\
\end{array}$ & B \\
\hline 20 & $\overline{\mathrm{YO}}$ & 145 & 72.5 & $S$ & 155 & 77.5 & B \\
\hline \multicolumn{2}{|c|}{ Jumlah } & 2904 & $\begin{array}{c}145 \\
2\end{array}$ & & 3207 & $\begin{array}{c}160 \\
4\end{array}$ & \\
\hline & Mean & 145 & 72.6 & $\mathbf{S}$ & 160 & $\begin{array}{c}80.1 \\
8\end{array}$ & B \\
\hline
\end{tabular}

Berdasarkan data pretest dan posttest yang dapat dilihat pada tabel 1 diketahui bahwa terjadi peningkatan kebiasaan belajar pada keseluruhan siswa dari kelompok eksperimen, ini berarti dari data pretest dan posttest yang diperoleh diketahui bahwa terjadi peningkatan kebiasaan belajar siswa pada kelompok eksperimen setelah diberikan layanan informasi dengan pendekatan problem based learning. Perbedaan hasil pretest dan posttest kebiasaan belajar siswa juga dapat dilihat pada grafik dibawah ini:

\section{Grafik 1}

Perbedaan Hasil Pretest dan Posttest Kebiasaan Belajar Siswa Kelompok Eksperimen

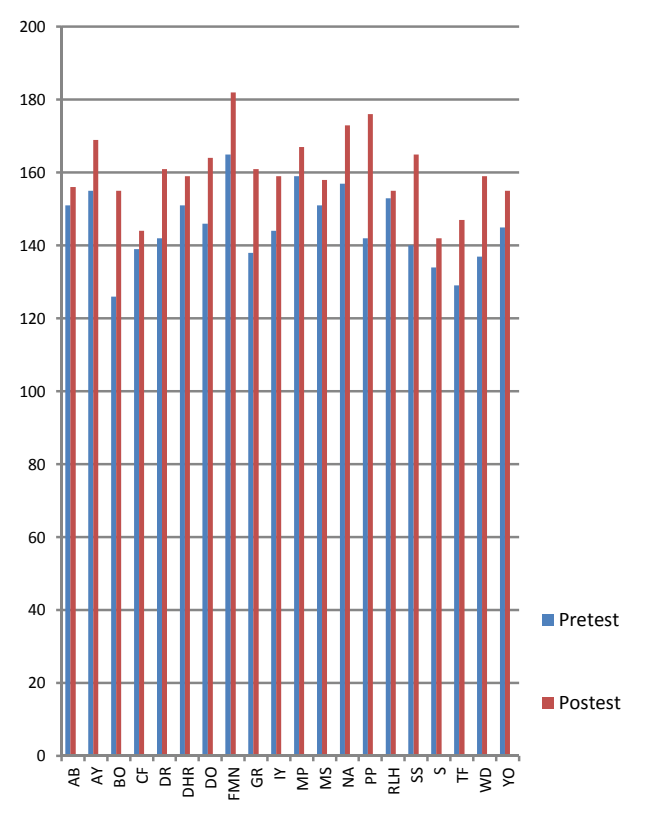

Berdasarkan grafik di atas, dapat dilihat terdapat peningkatan secara keseluruhan hasil pretest dan posttest siswa pada kelompok eksperimen yang dilaksanakan layanan informasi dengan pendekatan problem based learning.
Sebelum dan Setelah Diberikan Layanan Informasi dengan Pendekatan Problem Based Learning Pada Kelompok Eksperimen
2. Perbedaan Kebiasaan Belajar Siswa Kelompok Kontrol Pada Pretset dan Posttest 
Tanpa Dilaksanakan Layanan Informasi dengan Pendekatan Problem Based Learning

\begin{tabular}{|c|c|c|c|c|c|c|c|}
\hline \multirow{3}{*}{$\begin{array}{l}\mathbf{N} \\
\mathbf{O}\end{array}$} & \multirow{3}{*}{$\begin{array}{c}\text { Respon } \\
\text { den }\end{array}$} & \multicolumn{6}{|c|}{ Kelompok Kontrol } \\
\hline & & \multicolumn{3}{|c|}{ Pretest } & \multicolumn{3}{|c|}{ Postest } \\
\hline & & Skor & $\%$ & $\begin{array}{l}\text { Kate } \\
\text { gori }\end{array}$ & Skor & $\%$ & $\begin{array}{l}\text { Kate } \\
\text { gori }\end{array}$ \\
\hline 1 & AT & 145 & 72.5 & $\mathrm{~S}$ & 145 & 72.5 & $S$ \\
\hline 2 & $A D$ & 155 & 77.5 & $\mathrm{~B}$ & 148 & 74 & $S$ \\
\hline 3 & BDP & 126 & 63 & SR & 129 & 64.5 & $\mathrm{R}$ \\
\hline 4 & $\mathrm{CO}$ & 136 & 68 & $\mathrm{R}$ & 141 & 70.5 & $\mathrm{~S}$ \\
\hline 5 & $\mathrm{CA}$ & 142 & 71 & $S$ & 149 & 74.5 & B \\
\hline 6 & FR & 148 & 74 & $\mathrm{~S}$ & 149 & 74.5 & $B$ \\
\hline 7 & $\mathrm{IK}$ & 146 & 73 & $\mathrm{~S}$ & 146 & 73 & $S$ \\
\hline 8 & JAK & 158 & 79 & $B$ & 158 & 79 & $B$ \\
\hline 9 & MAP & 138 & 69 & $\mathrm{R}$ & 139 & 69.5 & $S$ \\
\hline 10 & MM & 141 & 70.5 & S & 149 & 74.5 & B \\
\hline 11 & NY & 157 & 78.5 & B & 147 & 73.5 & $\mathrm{~S}$ \\
\hline 12 & NF & 147 & 73.5 & $\mathrm{~S}$ & 151 & 75.5 & $B$ \\
\hline 13 & OR & 154 & 77 & B & 146 & 73 & $S$ \\
\hline 14 & PR & 142 & 71 & $S$ & 150 & 75 & $B$ \\
\hline 15 & Q & 145 & 72.5 & S & 136 & 68 & $\mathrm{R}$ \\
\hline 16 & QA & 140 & 70 & $\mathrm{~S}$ & 140 & 70 & $\mathrm{~S}$ \\
\hline 17 & RM & 131 & 65.5 & $\mathrm{R}$ & 140 & 70 & $\mathrm{~S}$ \\
\hline 18 & SA & 132 & 66 & $\mathrm{R}$ & 140 & 70 & S \\
\hline 19 & VM & 131 & 65.5 & $\mathrm{R}$ & 140 & 70 & $\mathrm{~S}$ \\
\hline 20 & YW & 142 & 71 & $\mathrm{~S}$ & 142 & 71 & $\mathrm{~S}$ \\
\hline \multicolumn{2}{|c|}{ Jumlah } & 2856 & $\begin{array}{c}142 \\
8\end{array}$ & & 2885 & $\begin{array}{l}144 \\
2.5\end{array}$ & \\
\hline & Mean & 142.8 & 71.4 & S & $\begin{array}{c}144.2 \\
5\end{array}$ & $\begin{array}{c}72.1 \\
25\end{array}$ & $S$ \\
\hline
\end{tabular}

Tabel 2

Hasil Pretest dan Posttest Kebiasaan Belajar Siswa Kelompok Kontrol
Berdasarkan data pretest dan posttest yang terlihat pada tabel 2 diketahui bahwa terjadi peningkatan Kebiasaan belajar siswa pada sebelas orang dari dua puluh siswa dalam kebiasaan belajar pada kelompok kontrol, lima orang tidak mengalami peningkatan pada kebiasaan belajarnya, sedangkan pada empat orang siswa lainnya mengalami penurunan tingkat kebiasaan belajarnya, itu berarti dari data tersebut dapat diketahui bahwa tidak semua siswa anggota kelompok kontrol mengalami peningkatan pada kebiasaan belajar . perbedaan hasil pretest dan posttest kebiasaan belajar siswa pada kelompok kontrol juga dapat dilihat pada grafik dibawah ini:

Grafik 2

Perbedaan Hasil Pretest dan Posttest Kebiasaan Belajar Siswa Kelompok Kontrol

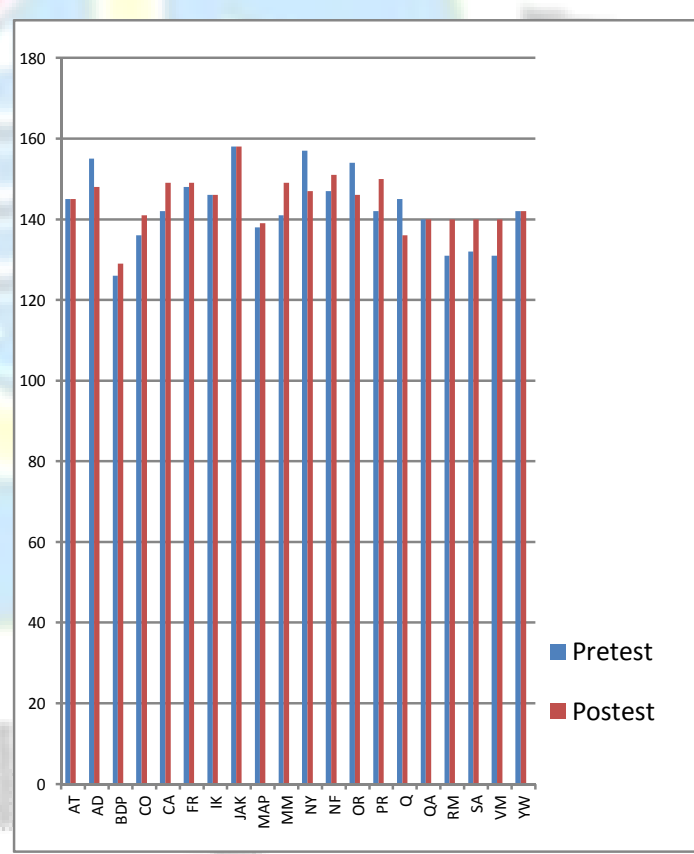

Berdasarkan grafik diatas, dapat dilihat bahwa tidak terdapat peningkatan secara keseluruhan pada siswa kelompok kontrol pada hasil pretest dan posttest tanpa dilaksanakan layanan informasi dengan pendekatan problem based learning. 
Hasil Pretest dan Posttest Kelompok

Eksperimen dengan Kelompok Kontrol

\begin{tabular}{|c|c|c|c|c|c|c|}
\hline \multirow[t]{2}{*}{$\mathrm{NO}$} & \multirow{2}{*}{$\begin{array}{l}\text { Kode } \\
\text { Respon } \\
\text { den }\end{array}$} & \multicolumn{2}{|r|}{ Eksperimen } & \multirow{2}{*}{$\begin{array}{c}\text { Kode } \\
\text { Respon } \\
\text { den }\end{array}$} & \multicolumn{2}{|c|}{ Kontrol } \\
\hline & & Pretest & Posttest & & Pretest & Postest \\
\hline 1 & $\overline{\mathrm{AB}}$ & 151 & 156 & AT & 145 & 145 \\
\hline 2 & $\mathrm{AY}$ & 155 & 169 & $\mathrm{AD}$ & 155 & 148 \\
\hline 3 & $\mathrm{BO}$ & 126 & 155 & BDP & 126 & 129 \\
\hline 4 & $\mathrm{CF}$ & 139 & 144 & $\mathrm{CO}$ & 136 & 141 \\
\hline 5 & DR & 142 & 161 & $\mathrm{CA}$ & 142 & 149 \\
\hline 6 & DHR & 151 & 159 & FR & 148 & 149 \\
\hline 7 & DO & 146 & 164 & IK & 146 & 146 \\
\hline 8 & FMN & 165 & 182 & JAK & 158 & 158 \\
\hline 9 & GR & 138 & 161 & MAP & 138 & 139 \\
\hline 10 & IY & 144 & 159 & MM & 141 & 149 \\
\hline 11 & MP & 159 & 167 & $\mathrm{NY}$ & 157 & 147 \\
\hline 12 & MS & 151 & 158 & $\mathrm{NF}$ & 147 & 151 \\
\hline 13 & NA & 157 & 173 & OR & 154 & 146 \\
\hline 14 & PP & 142 & 176 & PR & 142 & 150 \\
\hline 15 & RLH & 153 & 155 & $\mathrm{Q}$ & 145 & 136 \\
\hline 16 & SS & 140 & 165 & QA & 140 & 140 \\
\hline 17 & $\mathrm{~S}$ & 134 & 142 & $\mathrm{RM}$ & 131 & 140 \\
\hline 18 & $\mathrm{TF}$ & 129 & 147 & SA & 132 & 140 \\
\hline 19 & WD & 137 & 159 & VM & 131 & 140 \\
\hline 20 & $\mathrm{YO}$ & 145 & 155 & YW & 142 & 142 \\
\hline & umlah & 2904 & 3207 & & 2856 & 2885 \\
\hline & Mean & 145 & 160 & & 142,8 & 144,25 \\
\hline & ategori & S & B & & $\mathbf{S}$ & $\mathrm{S}$ \\
\hline
\end{tabular}

Berdasarkan data pretest dan posttest yang dapat dilihat pada tabel 3 diketahui bahwa terjadi peningkatan Kebiasaan belajar siswa setelah diberikan layanan informasi dengan pendekatan problem based learning pada kelompok eksperimen, namun perbedaan peningkatan kebiasaan belajar pada kelompok eksperimen lebih besar dibandingkan perbedaan peningkatan pada kelompok kontrol. Selain itu dari tabel dapat dilihat bahwa hampir keseluruhan siswa pada kelompok eksperimen mengalami peningkatan setelah diberikan layanan infromasi dengan pendekatan problem based learning, sedangkan pada kelompok kontrol masih terdapat beberapa siswa yang tidak mengalami peningkatan pada kebiasaan belajar. Itu berarti bahwa pemberian layanan informasi dengan pendekatan problem based learning lebih efektif dalam meningkatkan kebiasaan belajar siswa.

\section{PEMBAHASAN}

Pada bagian ini akan dikemukakan pembahasan hasil temuan penelitian mengenai peningkatan kebiasaan belajar siswa.

\section{Perbedaan Kebiasaan Belajar Siswa} Kelompok Eksperimen Pada Pretest dan Posttest Setelah Dilaksanakan Layanan Informasi dengan Pendekatan Problem Based Learning

Berdasarkan hasil penelitian yang dilakukan melalui eksperimen dengan materi tentang masalah yang berkaitan dengan kebiasaan belajar, ternyata peningkatan kebiasaan belajar siswa dalam mengikuti layanan informasi dengan pendekatan problem based learning kelompok eksperimen hampir secara keseluruhan menunjukkan adanya perbedaan secara signifikan antara sebelum dan sesudah mengikuti layanan informasi dengan pendekatan problem based learning. Hal

\section{Perbedaan Peningkatan Kebiasaan Belajar Siswa Pada Kelompok Eksperimen dengan Kelompok Kontrol}

Tabel 3 tersebut berarti adanya pengaruh dari kegiatan layanan informasi dengan pendekatan problem based learning. Sejalan dengan hal itu Kunandar (2010:354) keunggulan pendekatan problem based learning yaitu dapat melatih siswa untuk belajar tentang cara berfikir kritis dan 
keterampilan memecahkan masalah serta untuk memperoleh pengetahuan yang baru. Dengan demikian pendekatan pembelajaran ini akan melibatkan siswa menjadi aktif untuk memecahkan masalah sehingga siswa dapat mempelajari pengetahuan yang berhubungan dengan masalah tersebut.

Menurut Prayitno (2012:50) tujuan umum layanan informasi (INFO) adalah dikuasainya informasi tertentu oleh peserta layanan. Informasi tersebut selanjutnya digunakan oleh peserta untuk keperluan hidupnya sehari-hari (dalam rangka kehidupan efektif sehari-hari---KES) dan perkembangan dirinya. Dengan diadakannya layanan informasi dengan pendekatan problem based learning dengan materi yang berkenaan dengan permasalahan yang berkaitan dengan kebiasaan belajar siswa agar dapat siswa dapat membiasakan dirinya untuk terus belajar, serta mandiri untuk memecahkan permasalahan yang dihadapinya.

Sejalan dengan hal diatas, Prayitno (2004:6) menjelaskan bahwa layanan informasi adalah bagian dari salah satu layanan dalam bimbingan dan konseling yang diberikan kepada siswa untuk menambah wawasan siswa terhadap suatu hal yang bermanfaat untuk mengenali diri seperti pertumbuhan tubuh, mengembangkan sikap dan kebiasaan belajar.

2. Perbedaan Kebiasaan Belajar Siswa Kelompok Kontrol Pada Pretest dan Posttest Tanpa Dilaksanakan Layanan Informasi dengan Pendekatan Problem Based Learning

Berdasarkan data hasil penelitian perbedaan dari pretest dan posttest dari kelompok kontrol yang berjumlah 20 orang siswa terdapat 11 orang yang mengalami peningkatan kebiasaan belajar. Sedangkan yang mengalami penurunan terdapat 4 orang siswa dan yang tidak terdapat perubahan yaitu 5 orang siswa. Perubahan yang terjadi pada kelas kontrol dikarenakan siswa tidak mendapatkan perlakuan khusus yaitu layanan informasi dengan pendekatan problem based learning melainkan hanya mendapatkan layanan dari guru bimbingan dan konseling di sekolah saja.

Dengan demikian terlihat bahwa kebiasaan belajar siswa kelompok kontrol secara keseluruhan tidak mengalami perubahan.

\section{Perbedaan Peningkatan Kebiasaan Belajar Siswa Pada Kelompok Eksperimen dengan Kelompok Kontrol}

Hipotesis ketiga yang berbunyi "Terdapat perbedaan yang signifikan pada kebiasaan belajar siswa kelompok eksperimen yang mengikuti layanan informasi dengan pendekatan problem based learning dengan kebiasaan belajar siswa kelompok kontrol yang tidak diberikan perlakuan layanan informasi dengan pendekatan problem based learning.. Hipotesis tersebut diuji dengan menggunakan Two Sample Kolmogorov-Smirnov Test menggunakan program SPSS versi 20. Hasil dari pengujian tersebut diperoleh bahwa memang terdapat perbedaan skor peningkatan kebiasaan belajar siswa antara kelompok eksperimen dan kelompok kontrol.

Terdapatnya perbedaan dari hasil-hasil posttest kedua kelompok ini salah satunya disebabkan oleh perlakuan yang diberikan pada masing-masing kelompok. Layanan informasi dengan pendekatan problem based learning merupakan layanan yang lebih efektif dalam meningkatkan kebiasaan belajar siswa. Layanan informasi dengan pendekatan problem based learning membantu siswa untuk berpikir dalam memecahkan suatu masalah yang dijadikan materi dalam layanan informasi. Sebagaimana dikemukakan oleh Tohirin (2007:147) layanan informasi bertujuan agar individu memahami berbagai informasi untuk mencegah timbulnya suatu masalah, pemecahan suatu masalah, dan untuk memelihara serta mengembangkan potensi individu agar dapat mengaktualisasikan hakhaknya sehingga tercipta kemandirian.

Layanan informasi adalah bagian dari salah satu layanan dalam bimbingan dan konseling yang diberikan kepada siswa untuk menambah wawasan siswa terhadap suatu hal yang bermanfaat untuk mengenali diri seperti pertumbuhan tubuh, mengembangkan sikap dan kebiasaan belajar (Prayitno, 2004:6).

Dengan demikian, layanan informasi dengan pendekatan problem based learning membantu peserta didik dalam pengembangan pribadi, kemampuan hubungan sosial, kegiatan belajar, karir/jabatan, dan pengambilan keputusan, serta melakukan kegiatan tertentu melalui kegiatan kelas yang beranggotakan sekitar 20 orang. Dan dengan kegiatan ini diharapkan dapat meningkatkan kebiasaan belajar siswa.

\section{KESIMPULAN DAN SARAN}

\section{Kesimpulan}

Berdasarkan temuan dari penelitian ini yaitu: (1) terdapat perbedaan yang signifikan pada kebiasaan belajar siswa yang mengikuti layanan informasi pada kelompok eksperimen sebelum dan setelah diberikan perlakuan layanan informasi dengan pendekatan problem based learning. (2) Tidak terdapat perbedaan yang signifikan pada kebiasaan belajar siswa kelompok kontrol yang tidak diberikan perlakuan layanan informasi dengan pendekatan 
problem based learning. Kebiasaan belajar siswa dalam mengikuti layanan informasi pada kelas kontrol secara keseluruhan tidak mengalami peningkatan, adapun beberapa orang siswa yang mengalami peningkatan pada hasil posttest tetapi tidak memberikan perbedaan yang signifikan. (3) Terdapat perbedaan yang signifikan pada peningkatan kebiasaan belajar siswa dalam mengikuti layanan informasi dengan pendekatan problem based learning pada kelompok eksperimen yang diberi perlakuan yaitu layanan informasi dengan pendekatan problem based learning dengan kelompok kontrol yang tidak diberi perlakuan layanan informasi dengan pendekatan problem based learning.

\section{Saran}

a. Guru Bimbingan dan Konseling, untuk terus meningkatkan dan mengembangkan layanan bimbingan dan konseling terutama layanan informasi dengan pendekatan problem based learning untuk meningkatkan kebiasaan belajar siswa.

b. Kepala sekolah SMPN 2 Sawahlunto, untuk lebih memperhatikan layanan bimbingan dan konseling terutama dalam penyediaan dan pengadaan sarana belajar umumnya seperti alat-alat yang dibutuhkan guru bimbingan dan konseling dalam membantu mengembangkan kompetensi siswa dan mendorong guru bimbingan dan konseling untuk melaksanakan layanan informasi.

c. Dinas Pendidikan Provinsi Sumatera Barat, untuk meningkatkan kinerja guru pembimbing dengan memberikan pelatihanpelatihan yang bertujuan untuk meningkatkan kompetensi guru pembimbing.

d. Dosen Jurusan Bimbingan dan Konseling Fakultas Ilmu Pendidikan Universitas Negeri Padang, sebagai bahan evaluasi serta mempersiapkan bahan dalam rancangan program bimbingan dan konseling. Serta untuk lebih meningkatkan kualitas mahasiswa sebagai calon guru bimbingan dan konseling agar dapat memberikan pelayanan terbaik kepada peserta didik, khususnya dalam memberikan layanan informasi.

e. Bagi peserta didik yang telah mengikuti layanan informasi dengan pendekatan problem based learning diharapkan dapat meningkatkan kebiasaan belajarnya dan agar tidak bosan untuk mengikuti kegiatan kegiatan yang dilakukan oleh guru bimbingan dan konseling. f. Bagi peneliti selanjutnya diharapkan dapat melanjutkan penelitian dengan jenis layanan bimbingan dan konseling yang lainnya.

\section{KEPUSTAKAAN}

Anas Sudijono.2009. Pengantar Evaluasi Pendidikan.Jakarta: Raja Grafindo Persada

Aunurrahman. 2012. Belajar Dan Pembelajaran. Bandung: ALFABETA.

Dewa Ketut Sukardi. 2008. Pengantar Pelaksanaan Program Bimbingan Dan Konseling Di Sekolah. Jakarta: Rineka Cipta.

Djaali. 2012. Psikologi Pendidikan. Jakarta: Bumi Aksara.

Frisa Indriyani. 2011. Hubungan Pemanfaatan Waktu Belajar Diluar Jadwal Belajar Sekolah Dengan Hasil Belajar Siswa Kelas VIII Dan IX SMP Pertiwi 1 Padang. Skripsi. Padang: FIP UNP.

Kunandar. 2010. Guru Profesional Implementasi Kurikulum Tingkat Satuan Pendidikan (KTSP) dan Sukses dalam Sertifikasi Guru. Jakarta: PT Grafindo Persada.

Prayitno dan Erman Amti. 2004. Dasar-dasar Bimbingan Dan Konseling. Jakarta: Rineka Cipta.

Prayitno dan Erman Amti. 2009. Dasar -dasar Bimbingan Dan Konseling. Jakarta: Rineka Cipta.

. 2012. Jenis Layanan dan Kegiatan Pendukung Konseling. Padang: Program PPK BK FIP UNP.

Sherly Yosevia. 2013. Kesadaran Siswa Dalam Menyelesaikan Tugas Terstruktur (PR) (Studi Deskriptif Terhadap Siswa SMP $N \quad 28$ Padang). Skripsi.Padang:FIP UNP.

Tohirin. 2007. Bimbingan dan Konseling di Sekolah dan Madrasah. Jakarta: Rajawali

Tulus Winarsunu. 2002. Statistik dalam Penelitian Psikologi \& Pendidikan. Malang: UMM Press.

Undang-Undang Republik Indonesia Nomor 20 Tahun 2003 tentang Sistem Pendidikan Nasional. Jakarta: Depdiknas. 
Wahid Sulaiman. 2003. Teori dan Pratik Bimbingan Kelompok. Jakarta: Depdibud.

Wina Sanjaya. 2012. Strategi Pembelajaran Berorientasi Standar Proses Pendidikan. Jakarta: Kencana Prenada Media Group.

Wulandari Cristal. 2013. Hubungan Keterampilan Mencatat Dengan Hasil
Belajar Siswa SMP Negeri 4 Padang Panjang. Skripsi. Padang: FIP UNP.

Yulianti. 2013. Pembelajaran Problem Based Learning. Online. http://www.scribd.com/doc/77893287/Me tode-Pembelajaran-Problem-SolvingDan-Learning.

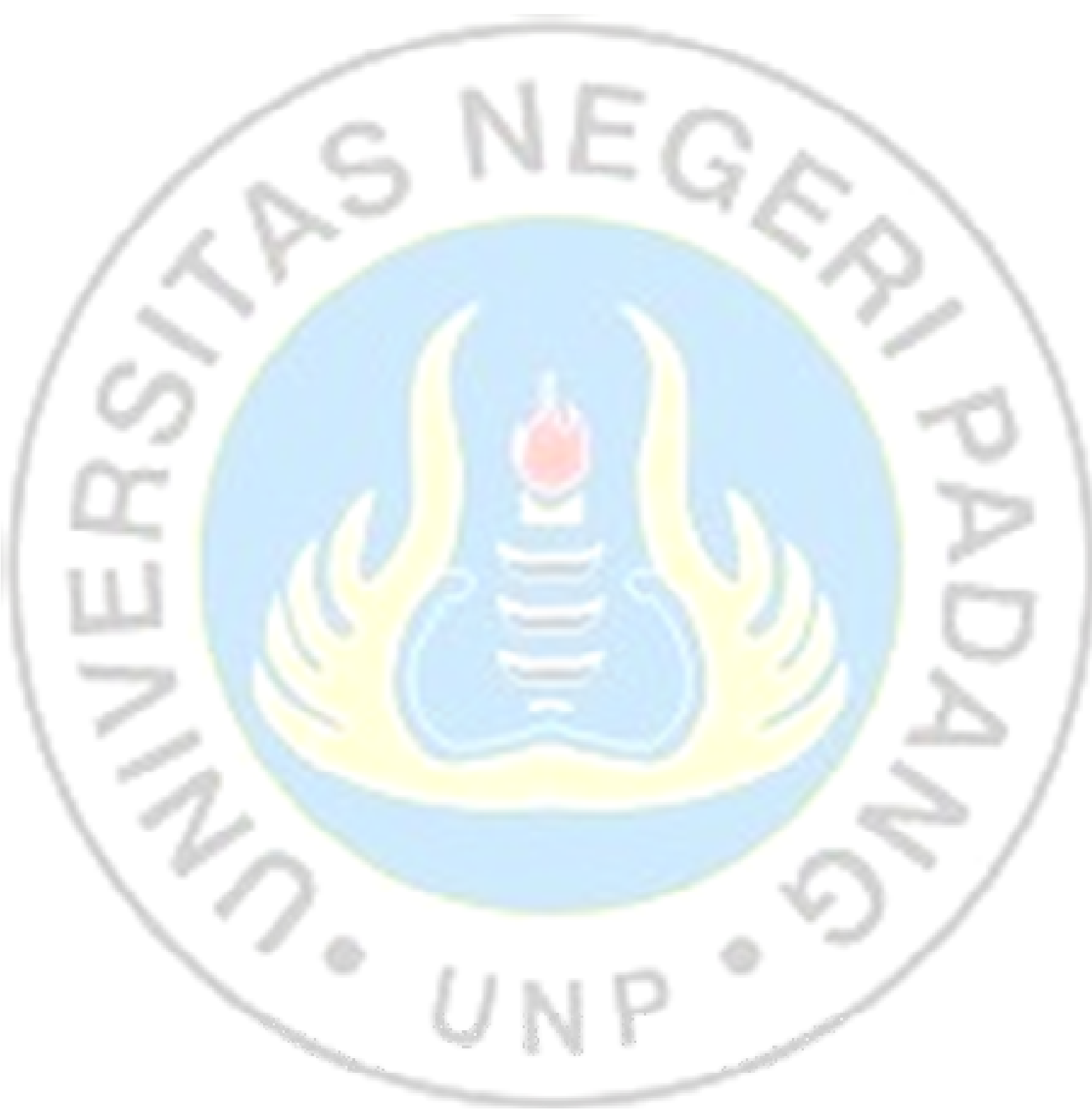

